\title{
Değerler Eğitimi ve Güncel Tartışmalar: Gazete Haberlerine iliş̧kin Bir Eleştirel Söylem Analizi ${ }^{*}$
}

\section{Values Education and Recent Debates: A Critical Discourse Analysis on Newspapers}

\author{
Ali Faruk YAYLACI ${ }^{\star *} \quad$ Adem BELDA $\check{G}^{\star \star *}$
}

Öz. Değerler eğitimi anlayışının etkisi, özellikle 2016 ve 2017 yılındaki öğretim programları güncelleme sürecinde, üzerinde çalışılan bütün öğretim programlarında görülebilir. Değerler eğitimi giderek daha yoğun bir ilginin hedefi olmaktadır. Yayınlanan makale ve yürütülen tez sayılarına yansıyan akademik ilginin yanında özellikle eğitim programlarına ilişkin son düzenlemeler değerler eğitimini kamuoyu nezdinde de önemli bir tartışma konusu haline getirmiştir. Bu bağlamda çalışmanın temel amacı değerler eğitimine ilişkin medya temsillerinin incelenmesi; bu incelemeye dayalı olarak çok boyutlu bir değerlendirme yapılmasıdır. Bu doğrultuda çalışma nitel bir araştırma olarak desenlenmiştir. Bu çerçevede, öğretim programları güncelleme çalışmalarına ilişkin taslakların kamuoyu tartışmasına açıldığı dönem dikkate alınarak 1 Ocak 2017 ve 7 Mart 2017 tarihleri arasında ulusal gazetelerde yer alan değerler eğitimi konulu haberler araştırmanın çalışma grubunu oluşturmuştur. Haberler sosyo-bilişsel yaklaşım çerçevesinde eleştirel söylem analizine dayalı olarak irdelenmiştir. Bulgulara göre gazeteler, değerler eğitimine oldukça sınırlı şekilde yer vermiştir ve değerler eğitimi, daha geniş toplumsal/siyasal çevredeki tartışmalar, kamplaşmalar ve ayrışmalara dayalı olarak haberleştirilmektedir.

Anahtar Kelimeler: Değerler eğitimi, eleştirel söylem analizi, evrim teorisi, gazete haberleri, öğretim programı.

Abstract. In articular, in the curricula updating process in 2016 and 2017, values education understanding can be seen in all draft curricula under construction. Values education is increasingly becoming the destination of more intense interest. Besides academic interest reflected in the number of published articles and thesis, recent regulations particularly regarding education curricula have made values education an important topic of debate in public opinion as well. In tis context. The aim of this study is to analyse the media representations concerning values education and carry out a multidimensional evaluation accordingly. To this end the study was designed as a qualitative study as it intended to analyse media representations of values education in connection with newspaper articles and to suggest a multidimensional evaluation. Due to the date when drafts of curriculum update studies were introduced to public debate, the news stories on values education appearing in nation-wide Turkish newspapers from January 1, 2017 to March 7, 2017 were appointed as study group. The news stories were reviewed with critical discourse analysis based on the socio-cognitive approach. According to the study findings, the newspapers spare very limited room for news about values education and values education was seen to be reported as news based on the basis of debates, polarizations and disintegration in the wider social/political environment.

Keywords: Critical discourse analysis, evolution theory, insructional program, newspapers, values education

\begin{abstract}
Toplumsal Mesaj.
$\mathrm{Bu}$ çalışmanın temel amacı değerler eğtiimine ilişkin olarak ulusal gazetelerde yer alan haberleri eleştirel söylem analizi değerlendirebilmektir. Çalışmanın bulgularına göre, gazeteler, değerler eğitimine oldukça snırlı bir çerçevede yer vermektedir. Gazeteler, değerler eğitiminin kendine özgü niteliklerinden çok politik kamplaşmaların etkisini güçlü bir biçimde yansıtmaktadır.
\end{abstract}

\section{Public Interest Statement.}

This study mainly aims to evaluate the news in the national newspapers related values education, based on critical discourse analysis. According to the findings of the study, the newspapers have a fairly limited framework for values education news. The newspapers strongly reflect the influence of political polarizations rather than the pecular qualities of values education.

\footnotetext{
* Çalışmanın taslak hali USBES 2017'de sözlü bildiri olarak sunulmuştur.

** Yrd. Doç. Dr., Dumlupınar Üniversitesi, Eğitim Fakültesi, Eğitim Yönetimi Anabilim Dalı, ali.yaylacı@dpu.edu.tr

*** Yrd. Doç. Dr., Recep Tayyip Erdoğan Üniversitesi Eğitim Fakültesi, Sosyal Bilgiler Eğitimi Anabilim Dalı, adem.beldag@erdogan.edu.tr
} 


\section{GiRiş}

Insanlık tarihi boyunca toplumsal yaşamı düzenleyen bir takım yazılı ve yazılı olmayan kurallar var olmuştur. Birey-birey ve birey-toplum arasındaki ilişkileri düzenleyen yönüyle öne çıkan bu kurallar kültür, inançlar, gelenekler, tarihsel miras ve dilin etkisi ile şekillenir. Aktaş ve Beldağ (2017), tarafından da toplumun ortak duygu ve düşünceleri olarak tanımlanan bu kurallar, kişinin davranışlarına yön veren değerler olarak ifade edilmektedir. Değerler davranışların, inançların ve tutumların yargılandığı ölçütlerdir (Zarillo, 2012). Bir şeyin arzu edilebilir veya edilemez olduğu hakkındaki inanç (Güngör, 1998) olarak tanımlanan değer kavramı toplumun çoğunluğu tarafından doğruluğu ve gerekliliği kabul edilen birleştirici unsurlar olarak görülmektedir (MEB, 2005). Gerçekte değerler, eğitsel süreçlerin bütün boyutlarında yer alırlar ve değerlerden bağımsız bir eğitim düşünmek imkânsızdır (Sutrop, 2015). Öğrencilerin karakterinin gelişimini destekleyen eğitim uygulamaları (Berkowitz, 2011) olarak ifade edilen değerler eğitimi anlayışı kavramsal olarak özellikle son yüzyılda gelen toplumsal değişimlerin sonucunda ortaya çıkmıştır (Kenan, 2009; Lickona, 1991). Böylece değerler eğitimi öğretim programlarında farklı biçimlerde yer almaya başlamıştır.

Değerler eğitimi anlayışı, dünyada değerler bağlamında yaşanılan toplumsal sorunları ve değerlerden uzaklaşmaya yol açı̆ı̆ı varsayılan eğitim sistemlerinin eksikliklerini gidermeye dönük bir eğilim olarak daha çok gündeme gelmektedir. Bu durumun Türkiye'deki yansıması ise ilk kez 2005 yılında Sosyal Bilgiler öğretim programı ile görülmüş, daha sonra farklı derslerde (Hayat Bilgisi, Medya Okur-yazarlı̆̆ı) değerler eğitimi yer almıştır. Günlük hayatta ahlak ve değer kazandırmanın birçok yolu olmasına rağmen işlevselliğinden dolayı öğretim programları tercih edilmektedir Zhu (2006). Özellikle 2017 öğretim programları güncelleme sürecinde değerler eğitimi anlayışı üzerinde çalışılan bütün taslak öğretim programlarında gözlemlenmektedir. Yine aynı şekilde 2018 yılında son şeklini alan öğretim programlarında da "Değerlerimiz öğretim programlarının perspektifini oluşturan ilkeler toplamıdır" ifadesiyle önem atfedilmektedir. Ayrıca 2018 öğretim programlarında (temel eğitim ve ortaöğretimde) "kök değerler" vurgusu yapılmış ve bu değer ifadeleri "adalet, dostluk, dürüstlük, öz denetim, sabır, saygı, sevgi, sorumluluk, vatanseverlik, yardımseverlik“ olarak programlarda yerini almıştır (MEB, 2018).

Değerler eğitimi giderek daha yoğun bir ilginin hedefi olmaktadır. Bu durum kendini akademik çalışmalarda da hissettirmektedir. Türkiye'de 1999-2015 yılları arasında 106'sı yüksek lisans, 20'si doktora derecesine sahip 126 tez yazıldığı ifade edilmiştir (Beldağ, 2016). Yayınlanan makale ve yürütülen tez sayılarına yansıyan akademik ilginin yanında özellikle eğitim programlarına ilişkin son düzenlemelerin sonu olarak değerler eğitimini kamuoyu nezdinde de önemli bir tartışma konusu haline getirmiştir. Söz konusu tartışma medyanın da ilgisini çekmiş ve bu konuda çeşitli gazetelerde çok sayıda haber yapılmıştır. Değerler eğitimi ve güncellenen programlar etrafındaki tartışmaların kamuoyuna yansıtılmasında ve bu tartışmaların biçimlendirilmesinde medyanın da önemli etkisi vardır. Taşdemir ve Kuş'un (2011) daha önceki bir program yenilenme sürecine ilişkin çalışmada vurguladıkları üzere yenilenen programların içeriği hakkında toplumsal tarafların bilgilendirilmesi açısından ulusal gazetelerde yer alan haberler oldukça önemli bir işleve sahiptir. De Swert ve diğerlerinin (2015) belirttiği üzere haberler, esasen toplumsal olarak inşa edilmektedir. Bu nedenle toplumsal olguların medyadaki temsilleri, bilgilendirme amaçı haberleştirmenin ötesinde birtakım niteliklere sahiptir. Aynı zamanda Herman ve Chomsky'nin (1988) vurguladığı üzere rıza üretiminde medyanın rolü (aktaran, Cohen, 2010) oldukça önemlidir. Haberlerde kullanılan söylemin analiz edilmesi bu açıdan önem taşımaktadır. Haberleştirme tarzları, karmaşık bir takım toplumsal, siyasal, ekonomik ya da kültürel etkenlerce biçimlendirilmektedir. Gazeteler hedef kitlelerinin düşüncelerine hitap edebilmek için haberleştirme tarzlarını bu düşüncelere duyarlı bir biçimde belirlemektedir. Aynı zamanda medya temsilleri yoluyla kamuoyunda belirli konularda toplumsal rızanın ya da tepkinin oluşturulması da hedeflenebilmektedir. Happer ve Philo'nun (2013) vurguladığı üzere medya dünyada meydana gelen olaylar hakkında kamuoyunun algılarını biçimlendirici bir işleve sahiptir. Bu süreçler gazetelerin temsil ettikleri düşüncelerin ve dünya görüşünün etkisiyle ortaya çıkmaktadır. Bu bağlamda Toruk ve Sine'nin (2012) değindiği üzere 
haberlerde yer alan ideolojik kodların anlaşılabilmesi için haberlerdeki örtük anlamların çözümlenmesi önem kazanmaktadır.

\subsection{Amaç}

Haberlerin ya da farklı yazılı metinlerin ve kullanılan söylemin incelenmesine yönelen çalışmalar bağlamında söylem analizlerinin 20. yüzyılın ikinci yarısından itibaren dünya ölçeğinde farklı disiplinlerde nitel bir araştırma yöntemi olarak kullanımı giderek artış göstermiştir (Gür, 2013; Rogers, vd., 2016). Özellikle politika analizleri bağlamında söylem analizleri ve eleştirel söylem analizleri artmaktadır (Taylor, 2004). 1980'lerin başlarından bu yana eğitim araştırmacıları da eleştirel söylem analizi aracılığıyla dil ve toplum arasındaki ilişkileri anlamaya dönük çalışmalarını artırmıştır ve eğitimin farklı alanlarında ve boyutlarında da eleştirel söylem analizlerinin yapılması gerektiği düşüncesi yaygınlaşmıştır (Rogers, vd., 2005). İdeolojilerin yeniden üretimi işlevi (Lim, 2014) dikkate alındığında eleştirel söylem analizi açısından eğitim, oldukça verimli bir alan niteliğindedir. Rogers ve diğerlerinin (2016) belirttiği üzere dünya ölçeğinde eğitim araştırmacıları eleştirel söylem analizini kullanmaktadır ancak bu çalışmalar daha çok ABD, Kanada, Birleşik Krallık ve Avustralya'da yoğunlaşmıştır. Türkiye'de de bu alanda yapılan çalışmalar sınırlı olmakla birlikte, zaman geçtikçe daha fazla bilimsel ürün ortaya konulmaktadır (Gür, 2013). Bu bağlamda çalışmanın temel amacı değerler eğitimine ilişkin medya temsillerinin incelenmesi; bu incelemeye dayalı olarak çok boyutlu bir değerlendirme yapılmasıdır.

\section{YÖNTEM}

\subsection{Araştırmanın Deseni}

Değerler eğitimine ilişkin medya temsillerinin, gazete haberleri bağlamında incelenmesi ve çok boyutlu bir değerlendirme yapılabilmesi amacından hareketle bu çalışma nitel bir araştırma olarak desenlenmiştir. 1 Ocak 2017 ve 7 Mart 2017 tarihleri arasında ulusal gazetelerde yer alan değerler eğitimi konulu haberler eleştirel söylem analizi bağlamında sosyo-bilişsel yaklaşım çerçevesinde değerlendirilmiştir.

\section{2 Çalışma Grubu}

Öğretim programları güncelleme çalışmalarına ilişkin taslakların kamuoyu tartışmasına açıldığı dönem dikkate alınarak 1 Ocak 2017 ve 7 Mart 2017 tarihleri arasında ulusal gazetelerde yer alan değerler eğitimi konulu haberler araştırmanın çalışma grubunu oluşturmuştur. Çalışma grubuna giren haberlere PRNet Programı aracılığıyla ulaşılmıştır. Bu çerçevede değerler eğitimi ile ilgili haberlerin yayınlandığı ve çalışma grubuna giren 15 gazete (alfabetik sırayla) şunlardır; Aydınlık, Birgün, Cumhuriyet, Güneş, Habertürk, Hürriyet, Karar, Milliyet, Posta, Sözcü, Star, Türkiye, Vatan, Yeni Akit, Yeni Şafak. Bu on beş gazetede 39 haber metni ve 11 köşe yazısı olmak üzere toplam 50 haber incelenmiştir.

\subsection{Verilerin Analizi}

Bulguların yorumlanması ve tartışma sürecinde öncelikle haberlerin genel özelliklerini ortaya koyabilmek için haber ve köşe yazılarının gazetelere göre sayıları, yayınlanma tarihine göre haberlerin dağılımı, genel olarak haberlerin konusuna ilişkin bulgulara yer verilmiştir. íkinci aşamada haberler eleştirel söylem analizi bağlamda değerlendirilmiştir. Genel anlamda eleştirel söylem analizi, eleştirel bir bakışla söylemlerin iktidar, ideoloji ve egemenlik gibi kuramsal kavramlara odaklanarak irdelendiği, sosyo-politik yorumlarla şekillenen bir çözümleme niteliğindedir (Khosravinik, 2009; Baker, vd., 2008 aktaran Göktuna Yaylacı, 2017). Eleştirel söylem analizinde, konu eleştirel bir nitelikte ele alınır ve kullanılan dilin toplum içinde biçimlenen yanı ile toplumsal olarak kurgulanan boyutlarının ilişkisi sorgulanmaktadır (Günay, 2013). Eleştirel söylem analizi, dili toplumsal bir pratik olarak görürken dilin kullanım bağlamının önemine odaklanır (Wodak ve Meyer, 2009). Sınıf, cinsiyet ve etnisite gibi sosyal özellikler ve bunların arasındaki ilişkiler, kendi sosyal, siyasi ve kültürel bağlamlarında metin ve sözün; yapısal birimleri, strateji ve seviyeleriyle sistematik olarak ilişkilidir (Van Dijk 1988: 138). Eleştirel söylem analizinin özgün niteliği 
dilin rolü, dilin kullanımı, söylem ya da eşitsizlik ve tahakkümün yeniden üretimindeki iletişimsel unsurları irdeleyebilmesidir (Gür, 2013). Bu çalışmada eleştirel söylem analizi Van Dijk'ın (2015) tanımlamış olduğu sosyo-bilişsel yaklaşımdan yola çıkılarak yapılmaya çalışılmıştır. Sosyo-bilişsel yaklaşım, bilgi, ideoloji ve sosyal gruplarca paylaşılan diğer inanışlar kadar, kullanıcıların söylem ürettiklerinde ya da bir söylemi idrak ettiklerinde ve sözel etkileşime katıldıklarında dil kullanımı süreci ve zihinsel temsillerinin araştırılması ile ilgilidir. Bu yaklaşım aynı zamanda, tahakküm ve toplumsal eşitsizlik gibi toplumsal yapılara olduğu kadar, söylemin yapısının, sözel etkileşimin ve iletişimsel durumların ilişkili olduğu bilişsel olguların incelenmesine yöneliktir (Van Dijk, 2009). Van Dijk'ın (2015), söylem-biliş-toplum üçgeni ile formüle ettiği sosyo-bilişsel yaklaşım ise bir metod olmaktan çok daha geniş bir çerçeveye atıf yapmaktadır. Eleştirel söylem analizinde söylem ve toplum arasındaki ilişkiye odaklanıırken sosyo-bilişsel yaklaşımda bu ilişkilerin bilişsel unsurların aracılığıyla gerçekleştiğini öne sürmektedir (Van Dijk, 2015: 63-64). Söylem-biliş-toplum üçgeni bağlamında haberler a) söylemsel ve semiyotik yapılar, b) bilişsel yapılar, c) toplumsal ve siyasal makro yapılar boyutlarında irdelenmiştir. Bu doğrultuda söylemsel ve semiyotik yapılar boyutunda özel başlıklar, olumsuz tanımlanışlar, sorumluluğun reddi/feragat, sözlük/söz dağarcığı ve diğer gramer yapıları, retorik klişeler, retorik düzen, motifler, argümantasyon ve mecazlar ele alınmıştır. Bilişsel yapılar boyutunda toplumsal olarak paylaşılan önyargılar ve ideolojiler bağlamında açıklanan ve yorumlanan söylem yapıları, zihinsel modeller ve sosyal biliş (dünya görüşü-bilgisi, tutumlar, ideolojiler) irdelenmiştir. Toplumsal ve siyasal makro yapılar boyutunda ise toplumsal biliş bağlamında toplumsal grupların üyeleri tarafından paylaşılan özel bilgi, tutum ve ideolojilere (Vand Dijk, 2015) dayalı bir değerlendirme yapılmıştır. Alanyazında eleştirel söylem analizine ilişkin olarak önyargılı dil kullanımı nedeniyle çeşitli eleştiriler getirilmiştir (Rogers, vd., 2016). Ancak bu eleştireler bütünüyle ve mutlak anlamda ön kabullerden bağımsız ve yine mutlak anlamda nesnel bir araştırmacı dilinin var olabileceğini varsaydığı için eleştirilebilir. Dolayısıyla bu çalışmada seçilen bazı haberlerdeki söylem çeşitli boyutları ile eleştirel bir analize tabi tutulurken araştırmacılar, mutlak anlamda yansız bir yerde konumlandıklarını iddia etmemektedir. Buna bağlı olarak ön kabullerden mutlak bağımsız bir dil kullanarak bulguların irdelediği ve yorumladığı da öne sürülmemektedir. Ancak, araştırmacının ve yazarın sübjektif konumunu göz önünde bulundurarak ve bulgulara ulaşma, çözümleme ve yorumlama yönteminin olabildiğince açıklanarak belirlenen bir durumun derinlemesine incelenmesine ve anlamlandırılmasına çalışımıştır. Bu süreç iki farklı araştırmacının yine olabildiğince görüş birliğine varabilmek için karşılıklı ve eleştirel bir yaklaşımla çalıştığı bir süreç olarak şekillenmiştir. Aynı zamanda toplumsal bir durumun ya da olgunun kendi konumlarını dürüstçe ve tutarlı bir biçimde belirlemiş araştırmacılar tarafından nasıl anlamlandırıldığının sergilenmesinin söz konusu toplumsal olgunun farklı taraflarca daha iyi anlamlandırılabilmesine katkı sağlayacağı söylenebilir.

\section{BULGULAR VE YORUMLAR}

Bu bölümde bulgular iki temel bölümde ele alınmıştır. Ilk bölümde değerler eğitimine ilişkin haberlerin genel özelliklerini ortaya koyan bulgular gazetelere göre haber ve köşe yazılarının sayıları, haberlerin yayın tarihleri, konuları, değerler eğitimine ilişkin genel yaklaşım, kullanılan fotoğraflar, haberlerin yer aldığı sayfalar gibi ölçütlere dayalı olarak ele alınmıştır. İkinci bölümde ise haberler, söylemsel/semiyotik yapılar, bilişsel yapılar ve toplumsal/siyasal makro yapılar boyutlarında tartışılmıştır.

\subsection{Haberlerin Genel Özellikleri}

Gazetelere göre haber sayılarına bakıldığında 1 Ocak 2017 ve 7 Mart 2017 tarihleri arasında değerler eğitimine ilişkin haberlerin 15 ulusal gazetede yer aldığı belirlenmiştir. Bu gazeteler alfabetik sıra ile şöyle sıralanabilir; Aydınlık, Birgün, Cumhuriyet, Güneş, Habertürk, Hürriyet, Karar, Milliyet, Posta, Sözcü, Star, Türkiye, Vatan, Yeni Akit ve Yeni Şafak. Anılan 15 ulusal gazetede toplam 50 haber/köşe yazısında değerler eğitimi konu edilmiştir. Gazetelerde yer alan haber sayıları Tablo 
1'de verilmiştir. Buna göre en fazla haber Yeni Akit (10), Hürriyet (8) ve Milliyet (6) gazetelerinde yer alırken 10 gazetede 1 ile 3 arası haber yer almıştır.

Tablo 1. Gazetelere Göre Haber Sayıları

\begin{tabular}{lc}
\hline Gazete & $f$ \\
\hline Aydınlık & 5 \\
Birgün & 3 \\
Cumhuriyet & 5 \\
Güneş & 1 \\
Habertürk & 1 \\
Hürriyet & 8 \\
Karar & 3 \\
Milliyet & 6 \\
Posta & 2 \\
Sözcü & 1 \\
Star & 1 \\
Türkiye & 2 \\
Vatan & 1 \\
Yeni Akit & 10 \\
Yeni Şafak & 1 \\
Toplam & 50
\end{tabular}

Gazetelere göre haber ve köşe yazılarının sayısına ilişkin bulgulara göre (Şekil 1) değerler eğitimine ilişkin 39 haber ve 11 köşe yazısı bulunmaktadır. En fazla köşe yazısı Yeni Akit ve Hürriyet gazetelerinde yer almıştır. Sözcü ve Star gazetelerinde ise sadece köşe yazılarının yer aldığı görülmüştür. Posta, Birgün, Hürriyet, Milliyet, Yeni Akit dışındaki gazetelerde sadece haber metinleri yer almıştır.

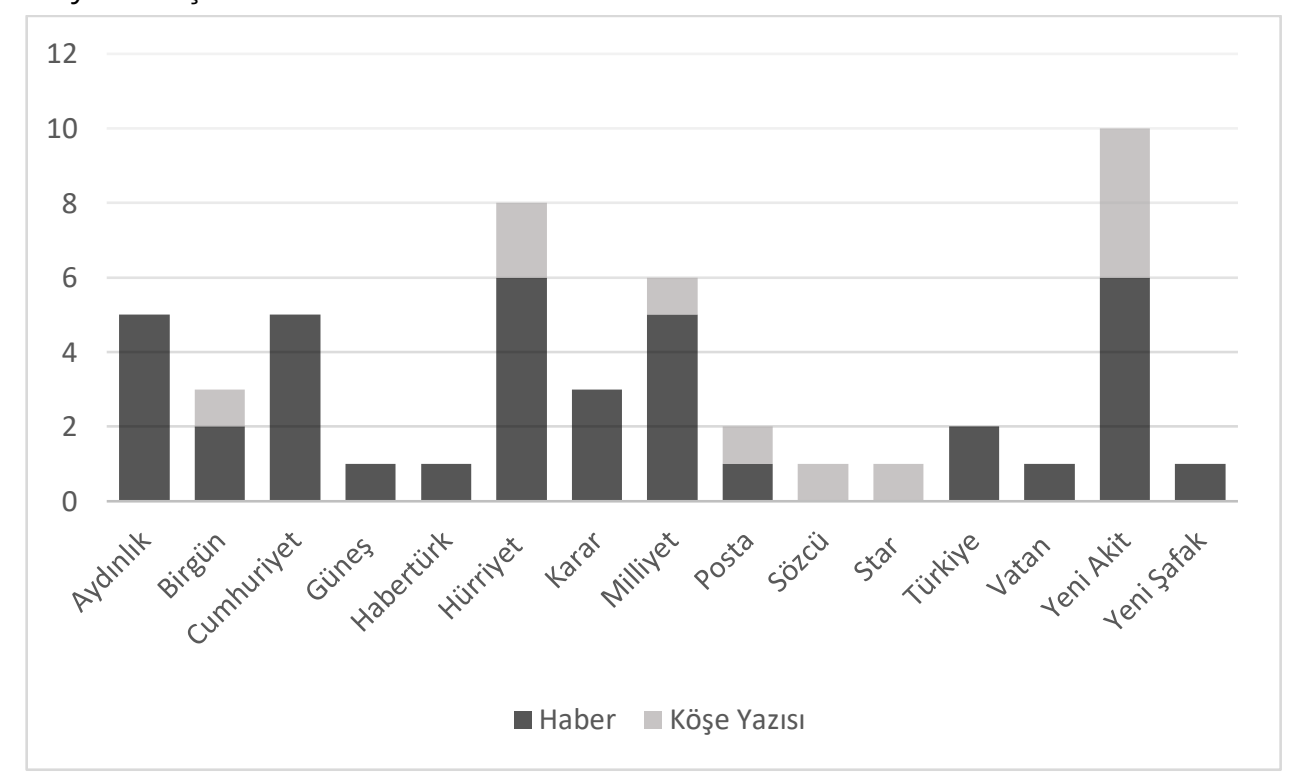

Şekil 1. Gazetelere Göre Haber ve Köşe Yazılarının Sayısı 
Yayın tarihlerine göre haberlere ilişkin bulgulara bakıldı̆̆ında (Şekil 2), öğretim programları güncelleme çalışmalarına ilişkin taslakların kamuoyu tartışmasına açıldığı dönemde bir miktar artış söz konusu olsa da ilerleyen zaman diliminde haber sayılarında fark edilir düzeyde azaldığı görülmektedir.

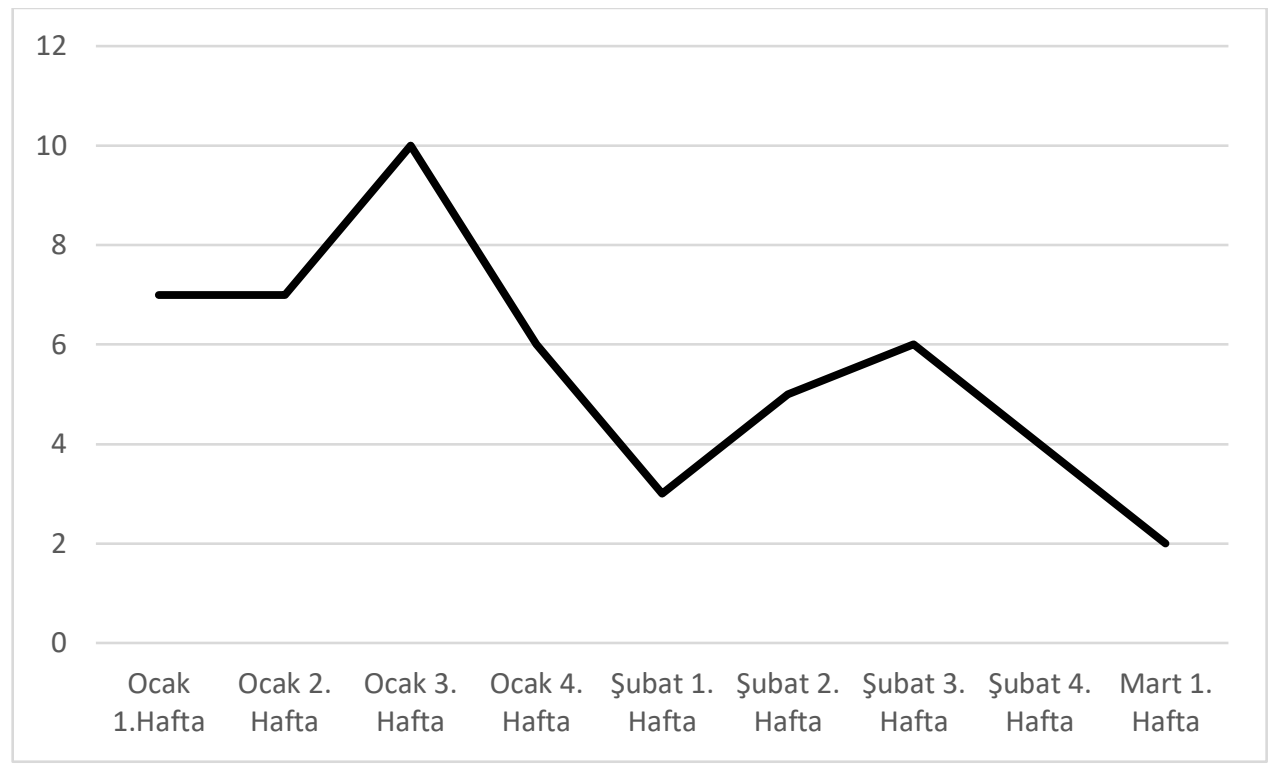

Şekil 2. Yayın Tarihlerine Göre Haberler

Değerler eğitimi haberlerinin konularına ilişkin bulgulara göre haberlerin yarısından fazlasının (Tablo 2) müfredat çalışmaları bağlamında olduğu bunun yanında yarıya yakınının ise değerler eğitimi uygulamalarına ilişkin olduğu bulgulanmıştır.

Tablo 2. Değerler Eğitimine İlişkin Olarak Haberlerin Konusu

\begin{tabular}{lc}
\hline Konu & $\mathrm{f}$ \\
\hline Değerler Eğitimi Uygulamaları & 22 \\
Müfredat Çalışmaları & 28 \\
Toplam & 50
\end{tabular}

Değerler eğitimi haberlerindeki genel yaklaşıma ilişkin bulgular (Tablo 3) incelendiğinde haberlerin yarısına yakınının olumsuz ve karşıt nitelikte olduğu diğer yarısının ise olumlu, destekleyici ya da betimleyici-yansız olduğu görülmüştür.

Tablo 3. Değerler Eğitimine İlişkin Olarak Haberlerdeki Genel Yaklaşım

\begin{tabular}{lc}
\hline Genel Yaklaşım & $\mathrm{f}$ \\
\hline Betimleyici- Yansız & 11 \\
Olumlu & 18 \\
Olumsuz & 21 \\
Toplam & 50
\end{tabular}

Değerler eğitimine ilişkin olarak haberlerde kullanılan fotoğraflara ilişkin bulgular (Tablo 4) konunun ele alındığı bağlamlar hakkında önemli ipuçları vermektedir. Bulgulara göre 11 haberde görsel kullanılmazken, en fazla öğrenci-öğretmen figürü kullanılmıştır (19 haber), ikinci sırada ise 6 haber ile bürokrat ya da siyasiler gelmektedir. STK Amblemi, Diyanet Amblemi, Atatürk, İnönü, Bayrak, 15 Temmuz gibi görseller ise değerler eğitimi ve müfredat çalışmalarının ele alındığı bağlam hakkında fikir vermektedir. 
Tablo 4. Değerler Eğitimine Illişkin Olarak Haberlerde Kullanılan Fotoğraflar

\begin{tabular}{lc}
\hline Fotoğraf & $f$ \\
\hline Öğrenci-Öğretmen & 19 \\
Bürokrat & 6 \\
Okul & 1 \\
STK Amblem & 3 \\
Diyanet Amblem & 1 \\
Bilim Adamı Darwin & 2 \\
Atatürk & 1 \\
Inönü & 1 \\
Bayrak & 1 \\
15 Temmuz & 1 \\
Anne-Çocuk & 1 \\
Masal Görseli & 2 \\
Günlük Yaşam & 2 \\
Görsel Yok & 11 \\
\hline
\end{tabular}

Değerler eğitimine ilişkin olarak haberlerin yer aldıkları sayfalar ve boyutlarına ilişkin bulgular, konuya görece az önem atfedildiğini düşündürmektedir. İlk sayfadan konuya yer veren gazete sayısı sadece 2'dir (Birgün ve Karar gazeteleri). 2 ve 9. Sayfalar arasında konuya yer veren gazete sayısı 17, 10 ve 19. Sayfalar arasında yer veren gazete sayısı 17, 20 ve sonrası sayfalarda verenlerin sayısı ise 9'dur. Haberlerin gazetelerde kapsadıkları alanlara bakıldığında ortalama 147,36 stXcm yer ayrıldığı görülmektedir. En Fazla yer ayıran gazete 424 stXcm ile Yeni Akit; 400 stXcm ile Milliyet ve 336 stXCM ile Habertürk olmuştur.

\subsection{Söylem, Biliş ve Toplum Bağlamında Haberler}

\subsubsection{Söylem açısından haberler}

Değerler eğitimi hakkındaki haberlerin genel olarak söylemsel yapısına bakıldığında değerler eğitimine ilişkin olarak yaklaşımın niteliğine göre belirgin bir biçimde farklılaştığı görülmektedir. Haberlerin yarısına yakını olumsuz, üçte biri olumlu diğerleri ise daha yansız bir yaklaşıma sahiptir. Özel başlıklar, olumsuz tanımlamalar, mecazlar gibi unsurları kapsamak üzere söylemsel açıdan incelendiğinde haberlerdeki özel başıkların, olumsuz/olumlu tanımlamaların ve kullanılan mecazların farklılaştığı görülmüştür. Ideolojik ve Ümmetçi (Cumhuriyet, 19.01.2017) başlığı, değerler eğitimine ve müfredat çalışmalarını olumsuz bir tanımlama ile aktarmaktadır. Yeni Müfredat is/am ve Irk Üzerine Kurulmuş (Birgün, 04.02.2017) başlıklı haber ise doğrudan müfredat çalışmalarını konu edinerek ırkçıllğa dayalı olmak gibi olumsuz bir tanımlamada bulunurken yine müfredat çalışmalarının İslam dini üzerine dayalı olduğunu vurgulayarak müfredatın dinsel niteliğini bir olumsuzluk olarak öne çıkarmıştır. Değerler eğitiminde din olmamalı (Hürriyet, 26.02.2017) başlığında yine değerler eğitimi ve müfredat çalışmalarının dini niteliği vurgulanmaktadır. Anne Çocuk Eğitim Vakfı (AÇEV) tarafından yapılan açıklamaların aktarıldığı haberde okul öncesi ve ilkokul programlarında yer alan değerler eğitiminin din öğretileri üzerine inşa edilmesinin çocukların gelişim özellikleri ile uyumlu olmadığı için doğru olmadığı, 'değerlerin evrensel tanımına ve bilimsel eğitim yaklaşımına uyacak şekilde kurgulanması gerektiği' dile getirilmiştir. Eğitimde Garip Uygulamalar (Saygı Öztürk-Sözcü, 29.01.2017) başlıklı yazıda MEB'nın dini bir vakıfla Değerler Eğitimi adı altında bir protokol imzaladığı ve daha çok dini eğitim verildiği aynı zamanda MEB okullarda umre ödüllü yarışmalar yapılmasına onay verildiği anlatılırken söz konusu çalışmalar Sinsi çalışmalar biçiminde ifade edilmiştir. Buna karşın genel olarak olumlu bir yaklaşıma sahip olan haberlerde kullanılan özel başlıklar ve mecazlar geleneksel değerler, din ve ülkede hâkim olan politik hedeflere uygun bir biçimde şekillenmiştir. Istikbal her zaman köklerdedir (Yeni Akit, 06.03.2017) başlıklı haberde geleneksel değerlerin önemi, Türkiye Cumhuriyeti'nin kurucu lideri 
Mustafa Kemal Atatürk'ün istikbal göklerdedir sözüne atıfla dile getirilmiştir. Bir ilin valisinin Necip Fazıl Sempozyumu nedeniyle yaptığı açıklamalarda kimlik ve kişilik oluşturma sorunu dile getirilerek, eğitime el atıldığı vurgulanmış ilk iş olarak değerler eğitimi çalışmaları yapıldı̆̆ı ifade edilmiştir. Haberde de dile getirildiği üzere 'geçmiş inmal edildi, istikbal göklerdedir'. Yeni Türkiye için Müfredata Neşter (Yeni Akit, 31.01.2017) başlı̆̆nda ise Türkiye'de yaşanmakta olan sosyo-politik değişimin ve Yeni Türkiye tartışmaları bağlamında olumlu ve destekleyici bir tanımlama dikkat çekmektedir. Benzer biçimde Kaya: Gençlerimizle 2023'e Yürüyoruz (Yeni Akit, 04.02.2017) başlı̆ında da bir siyasinin ifadesiyle 2023 hedefleri ile değerler eğitimi ve müfredat çalışmalarının ilişkisi destekleyici bir tarzda ifade edilmiştir. Ali Erkan Kavaklı́nın Eğitimde Nebevi Metoda ihtiyacımız Var başlıklı yazısı (Yeni Akit, 16.02.2017) ise değerler eğitimi ve müfredat bağlamında dini değerlerin önemini bir gereksinim çerçevesinde vurgulamaktadır. Yazara göre değerler eğitimi ders konuları içine serpiştirilecek ve bu şekilde milli manevi değerler önem kazanacaktır. Daha yansız bir yaklaşıma sahip haberlerde ise değerler eğitimine ilişkin etkinlik örneklerine yer verilirken, daha teknik denilebilecek eleştiriler dile getirilmekte, değerler eğitimi ve müfredat çalışmalarının yeniliği vurgulanarak yansıtılmaktadır; Yeni Müfredat Askıya Çıkıyor (Posta, 03.01.2017), Işste Yeni Müfredat (Karar, 14.01.2017). Müfredat Taslağına 175 bin görüş (Aydınlık, 12.02.2017). Yeni Müfredatta Bütünlük Yok (Vatan, 12.02.2017), 'Uzmanlar' olumlu olumsuz görüşlerini açıladılar. 'Değerler Eğitimi Merkezde', Değerler Eğitiminin Karşılı̆̆ı Net Değil (Hürriyet, 15.01.2017) başlıklı haberlerde görüldüğg̈ üzere olumsuz ve karşıt nitelikteki haberlerden farklı olarak bu kategorideki eleştirel haberlerde olumsuz tanımlamalardan çok betimleyici ve doğrudan değerler eğitiminin kendisine yönelik görüşler aktarılmıştır. Değerler eğitimine ilişkin olarak uygulama örnekleri ile ilgili haberlerde Mardin'de Ahlaklı Öğrenci Projesi (Milliyet, 17.02.2017) başlıklı haberde olduğu üzere öğrencilere milli ve manevi değerlerin kazandırılması, ahlaklı davranış örneklerinin sergilenmesi söz konusu edilmiştir. ilkokul Öğrencileri Durağın Sesi Oldu (Hürriyet, 06.03.2017) başlıklı haberde bir ilkokulun öğrencileri tarafından değerler eğitimini de kapsayan panoların okul yakınındaki bir durağa asılması aktarılırken Mihmandar Gençlik (Türkiye, 23.02.2017) başlıklı haberde bir belediyenin değerler eğitimi kapsamında öğrencilerin Bosna-Hersek'e ve Umreye götürülmesi anlatılırken inançlı, kültürlü, saygılı evlatlar tanımları öne çıkarılmıştır.

\subsubsection{Bilşsel yapılar açısından haberler}

Toplumsal olarak paylaşılan önyargılar ve ideolojiler, zihinsel modeller, sosyal bilişe (dünya görüşübilgisi, tutumlar, ideolojiler) dayalı olarak bilişsel yapılar (Van Dijk, 2015) bağlamında haberler irdelendiğinde belirgin bir ayrışma ve buna bağlı olarak ortaya çıkan keskin yorumlar dikkat çekmektedir. Olumlu ve destekleyici haberlerde milli, manevi, kültürel ve daha az sayıda olmakla birlikte evrensel değerlerin vurgulandığı ve değerler eğitiminin milli ve manevi köklere olan bağ|ı̆̆ sağlayacağı üzerinde durulmaktadır. Olumsuz ve karşıt nitelikli haberlerde ise konunun ele alınışının Evrim, Atatürk, Din bağlamında gerçekleştiği görülmektedir. Olumlu nitelikteki haberleri yayınlayan gazetelerin yeni müfredat çalışmalarında ve bu bağlamda değer eğitimine ilişkin olarak milli ve manevi köklere dönüş ya da yeni Türkiye'nin milli ve manevi değerlerle inşa edilmesi olarak gördükleri süreç diğer gazetelerde eğitimin giderek daha çok dinselleşmesi, bilimden uzaklaşması ve Atatürkçülüğün eğitimin içeriğinde zayıflatılması olarak görülmektedir. Incelenen gazetelerin siyasi duruşları ve kendilerini tanımlayışları ve buna bağlı olarak hitap ettikleri kitlelerin nitelikleri dikkate alındığında değerler eğitiminin haberlerde ele alınış tarzının beklenir bir durumu yansıttığı söylenebilir. Olumsuz yaklaşıma sahip haberler kategorisindeki ideolojik ve Ümmetçi (Cumhuriyet, 19.01.2017); Yeni Müfredat İslam ve Irk Üzerine Kurulmuş (Birgün, 04.02.2017); Değerler eğitiminde din olmamalı (Hürriyet, 26.02.2017); Vahiylerin Eğitimine Hayır (Turan Eser-Birgün, 31.01.2017): Evrim Müfredattan Çıkıyor (Habertürk,14.01.2017); Evrim Teorisi ve Atatürk Yok (Cumhuriyet,14.01.2017); ilkokuldan Atatürk'ü Çıkardılar (Aydınlık, 15.01.2017); Ilkokuldan Liseye Atatürk'ü Sildiler (Aydınlık, 12.02.2017). Inönü Başlı̆ı Çıkarıldı (Hürriyet, 16.01.2017); Atatürk'ü Çıkarıp ibadeti Koydular (Aydınlık, 18.01.2017); Evrim Olmadan Coğrafya da işlenemez (Hürriyet, 15.02.2017); başlıklı haberlerde verilmek istenen mesajlar paylaşılmış sosyokültürel bilgi bağlamında anlam kazanmaktadır. Bu bağlamda söz konusu haberlerin ülkedeki iktidar tartışmalarıyla yakından ilişkili olduğu 
söylenebilir. İtidara eleştirel bakan ya da karşıt konumundaki kesimlerin ülkede yaşanmakta olan dönüşümlerin dinselleşme yolunda olduğuna ilişkin görüşleri bağlamında söz konusu haberlerde ve başlıklarda verilen mesajlar anlamlı hale gelmektedir. Buna göre değerler eğitimi ve müfredat çalışmaları ülkede yaşanmakta olan dinselleşme ve Atatürkçülükten ve laiklikten uzaklaşma biçiminde yorumlanan gidişin sonucu olarak görülmektedir. Ideolojik ve Ümmetçi (Birgün, 19.01.2017) başlıklı haber bu yaklaşımın örneği niteliğindedir; Eğitim-i̇ş'in raporundan yapılan aktarımda müfredat çalışmalarının iktidar partisinin 16 yıllık yönetimi boyunca yaratmak istediği neslin özeti olduğu vurgulanmıştır. Atatürk'ü Çıkarıp ibadeti Koydular (Aydınlık, 18.01.2017) başıkı haberde de lise Türk Dili ve Edebiyatı ders kitaplarına değerler eğitimi adı altında inanç, ibadet, dua, din, maddi manevi temizlik, şükür konularını işleyen metinlerin koyulması haberleştirilmiştir. Evrim bağlamında dile getirilen mesajlarda ise yine iktidarın ya da müfredat çalışmalarını gerçekleştirenlerin bilimsellikten uzak olduklarına ilişkin algıya atıf yapıldığı söylenebilir. Bakanlık Müfredatı Sil Baştan Düzenledi Evrim Teorisi ve Atatürk Yok (Cumhuriyet, 14.01.2017), başlıklı haberde düzenlemenin sil baştan oluşu ve evrim ve Atatürk konuları özellikle vurgulanmıştır. Dini değerler, semboller ya da unsurlara ilişkin olarak keskin ve karşıt dil dikkat çekerken bu karşıtlığın din-bilim çatışmasına atıfla anlam kazandığı söylenebilir. Evrim Olmadan Coğrafya da iş̧lenemez (Hürriyet, 15.02.2017) başlıklı haberde yer alan “MEB'in değerler eğitimi yöntemi, diyalektik değil, dini-kültürel normların aşılanması şeklindedir. Temel insan hak ve özgürlükler ile eğitim ilkeleri ile ters düşmektedir" ifadeleri bu çerçevede düşünüldüğünde anlam kazanmaktadır. Benzer bir durum ülkede tartışmalı alanları açısından da geçerlidir. Eğitim-iş̧ ve bazı kurumların açıklamasının aktarıldığı haberde Türksüz, Atatürksüz müfredat olmaz (Birgün, 19.01.2017) denilerek söz konusu bağlama dayalı bir aktarım yapıldığı söylenebilir. Ancak Müfredat islamcılık Üzerine Kurulmuş (Birgün, 04.02.2017) başlıklı ve Eğitim-Sen'in hazırlamış olduğu raporun aktarıldığı haberde ise müfredatın İslamcılık ve Türkçülük üzerine kurulmuş olduğu vurgulanmıştır. Yine Evrim Olmadan Coğrafya da İşlenemez (Hürriyet, 15.02.2017) başlıklı haberde Tarih Vakfı ve ERG'nin görüşleri aktarılarak kadim Türklük, Kadim islam gibi ifadelerde sanki tek bir Türklük ve İslam varmış gibi davranıldığı anlatılmıştır. Bu durum Türkçülük, Türklük, ulusalcılık tartışmaları bağlamında kavramların oldukça muğlak olduğunu da göstermektedir. Başılılarda ve haberlerde kullanılan çıkardılar, koydular, kurulmuş attılar gibi ifadeler bu haber metinlerini hazırlayanların kendilerini değerler eğitimi ve müfredat çalışmalarını yapanlardan farkı gruplar olarak konumlandırdıklarını göstermektedir. Buradaki biz'in, Atatürkçü, ilerici, modern, bilimsel ve dine mesafeli olarak yansıtıldığı diğerleri'nin, ırkçı, bilimsellikten uzak, gelenekselci olarak konumlandırıldığı düşünülebilir.

Olumlu ve destekleyici nitelikteki başlıklı haberlerde verilmek istenen mesajlar da ülkede, iktidar öncülüğünde yaşandığı düşünülen dönüşüme ilişkin paylaşılmış sosyokültürel bilgiye dayalı olarak anlam kazanmaktadır. Bu mesajlarda iktidar tartışmaları bağlamında muhafazakâr demokrat olarak kendisini tanımlayan iktidarın öncülüğünde gerçekleşmekte olan toplumsal ve siyasal dönüşümlerin değerler eğitimi ve müfredat çalışmalarında yansıdığını ifade edilmektedir. istikbal her zaman köklerdedir (Yeni Akit, 06.03.2017) başlıklı haberde söz konusu dönüşümün köklere dönüş anlamı taşıdığı vurgulanır gibidir. Gençlerimizle 2023'e yürüyoruz (Yeni Akit, 04.02.2017) başlıklı haberde yaşanılan dönüşümün hedefi 2023 Vizyonu olarak anlatılırken; Yeni Türkiye için Müfredata Neşter (Yeni Akit, 31.01.2017) başlıklı haber de Yeni Türkiye hedefi için müfredat ve değerler eğitimi çalışmalarının yapıldığını açıklanmaktadır. Bu haberde yer alan Yeni Türkiye'nin 'Milli Eğitim' politikasında köklü değişimin önemli adımı. Değerler sisteminin eğitim sürecine dâhil olması, ilık Adımda Değerler Eğitimi gibi ifadeler söz konusu toplumsal ve politik dönüşümün gerçekleşebilmesi için eğitimin araçsallaştırıldığını düşündürmektedir. Yeni Türkiye kavramsalı ile ifade edilen dönüşümün ya da dönüşüm hedefinin geçmişte egemen olduğu düşünülen siyasal sistemden uzaklaşılması anlamına da geldiği söylenebilir. illgili bir köşe yazısında (Ali Erkan Kavaklı-Yeni Akit, 19.01.2017) müfredat çalışmalarının değerler eğitimi bölümünde Atatürk ilke ve inkılaplarını benimsetmek gibi ifadeler var olmaya devam etmesinin eleştirilmesi bu çerçevede anlaşılabilir. Yeni Türkiye'yi inşa etmek için müfredatın yenilenmesi ve değerler eğitimine merkezi bir yer 
verilmesine ilişkin olumlu görüşler, iktidarın kendi istediği düzeni kurmak üzere eğitim sistemini dönüştürdüğü yönündeki olumsuz görüşlerle örtüşüyor gibidir. Müfredat Önerisine Katkılar, Eleştiriler (Halime Kökçe-Star, 18.02.2017) başlıklı köşe yazısında ise Atatürkçülük etrafında varlığını sürdüren tartışmalara dayanılarak bir karşılaştırma yapılmıştır; Dini değerler eğitiminin birinci sınıfta başlamasına itiraz eden kurumlar, çocukların Atatürk kültü ile daha ana sınıfında tanıştırılmasının pedagojik izahını yapabiliyor mu? Sorusu Atatürkçülüğün neredeyse dini bir yaklaşımla ele alındığına ilişkin bir kabulü yansıtmaktadır.

\subsubsection{Toplumsal bağlam açısından haberler}

Toplumsal ve siyasal makro yapılar boyutunda, toplumsal biliş bağlamında toplumsal grupların üyeleri tarafından paylaşılan özel bilgi, tutum ve ideolojilere (Van Dijk, 2015) dayalı bir analiz yapıldığında üç temel sosyo-politik grubun varlığından söz edilebilir; değerler eğitimine ilişkin olarak olumsuz, olumlu ve görece yansız/eleştirel. Olumsuz yaklaşıma sahip haberler değerlendirildiğinde toplumsal ve siyasal makro yapılar düzeyinde bir tür propagandanın söz konusu olduğu söylenebilir. Söz konusu propaganda Türkiye açısından uzun bir geçmişe sahip olan laik/anti laik çatışması ile ilişkili korku ya da korkutma çabaları ile ilişkili görünmektedir. Ümmetçi, Ilkokuldan Atatürk'ü çıkardılar, Evrim müfredattan çıkarıldı gibi ifadeler söz konusu çatışma bağlamında Van Dijk'ın (2015) farklı bir çalışmada gözlemlediğine benzer bir şekilde, gazetelerin hitap ettiği okuyucu kitlesinin bağlam modeli kızgınlık ve tepki ortaya çıkarabilecektir. Benzer bir durum, destekleyici nitelikte haberlerde de görülmektedir. Bu haberler de toplumsal ve siyasal makro yapılar düzeyinde bu defa hedef kitlenin de bağlamsal modeli çerçevesinde yaşanmakta olan siyasal ve toplumsal dönüşümler konusunda sempati ve destek kazandırmaya dönük bir propaganda niteliğindedir. Yeni Türkiye için, istikbal köklerde, hedefe yürüyoruz gibi ifadelerde aynı zamanda geçmişte söz konusu olan düzen bağlamında olumsuz bir tepki yaratılmasına yol açılacağı söylenebilir. Söz konusu tepkileri ortaya çıkarmaya dönük haberleştirmeler aynı zamanda 2017 Nisan ayında yapılan referandum ile ilişkili bir biçimde de anlaşılabilir. Hedeflenen kızgınlık hayır oyu verilmesine, hedeflenen destek ise evet oyu verilmesine yönelik düşünüldüğünde anlamlı hale gelmektedir. Hayır'la geldiniz yerine Hoşgeldiniz-Welcome (Hürriyet, 23.02.2017) başlıklı haber bu bağlantıyı doğrular niteliktedir. Haberde, değerler eğitimi kapsamında okulun belirli yerlerine hayırlı evlat olasınız, hayırı vatandaş olasınız, hayırla geldiniz hayırla gidiniz gibi yazılar ve panolar asılması ancak bu okulun müdürünün referandum sürecinde, hayırcı müdür olarak adlandırılması ve bu nedenle panolardaki hayır ifadelerinin değiştirilmesi anlatılmıştır. Vahiylerin Eğitimine Hayır (Turan Eser-Birgün, 31.01.2017) başlıklı köşe yazısında ise İlamcı yapı ve kadrolar değerler eğitimi adı altında seminerler veriyorlar... Irkçı, mezhepçi, ayrımcı, tektipçi anlayış... Bütün bunlar için referandumda hayır denilerek tartışmanın seçim süreci ile ilişkisi doğrudan ifade edilmiştir.

\section{SONUÇ, TARTIŞMA VE ÖNERILER}

Değerler eğitiminin merkezi bir rol oynadığı müfredat yenileme çalışmalarına ilişkin taslağın kamuoyu görüşüne sunulduğu dönem dikkate alınarak 1 Ocak 2017 ve 7 Mart 2017 tarihleri arasında ulusal gazetelerde yer alan değerler eğitimi konulu haberlerin incelendiği bu çalışmada haberler, sosyo/bilişsel yaklaşım çerçevesinde eleştirel söylem analizine dayalı olarak irdelenmiştir. Çalışmanın bulgularına göre gazeteler değerler eğitimine oldukça sınırlı şekilde yer vermektedir. Değerler eğitiminin en azından incelenen dönem itibarı ile hak ettiği düzeyde ve eğitim bilimi bağlamında tutarlı bir biçimde ele alınmamış olduğu söylenebilir. Haberlerde değerler eğitimine ilişkin bir takım 'makbul' ya da bir takım 'tuhaf' örnekler verilirken alanın uzmanlarına ve alanyazındaki önemli tartışmalara yer verilmediği görülmektedir. Değerler eğitimi, eğitim sürecini de içine alan daha geniş toplumsal/siyasal çevredeki tartışmalar, kamplaşmalar ve ayrışmalara dayalı olarak haberleştirilmektedir. Değerler eğitimine ilişkin medya temsillerinde siyasi dünya görüşlerinin dramatik bir etkisi söz konusudur. Elbette eğitim siyasal bağlamdan bağımsız bir etkinlik değildir ve bu bağlamda tartışıması doğal ve kaçınılmazdır. Ancak bu durumda bile tarafsız 
ve adaletli bir biçimde eğitim biliminin verilerinden yararlanmamanın makul bir açıklaması olmadığı söylenebilir.

Bu çalışmanın değerler eğitimi ve müfredat çalışmaları bağlamındaki bulguları, Van Dijk'ın (2015: 73-74) söylemin ideolojik yapısına ilişkin özellikleri temelinde incelendiğinde görülmektedir ki gerek olumsuz gerek olumlu yaklaşıma sahip haberlerde kutuplaştırma yani olumlu iç grup, olumsuz dış grup tanımlayışı ve politik biz ve onlar ayrışması söz konusudur. Olumsuz yaklaşıma sahip haberlerde biz, Atatürkçü, laik ve bilimselci öteki dinci, ümmetçi, bilim karşıtı, gelenekçi olarak ifade edilirken olumlu ve destekleyici haberlerde biz Müslüman, muhafazakâr, yeni Türkiyeci, değerlere bağlı öteki ise ideolojik, laikçi, milli ve manevi değerlerden uzak eski Türkiye'ye ait biçiminde ifade edilmektedir. Söz konusu biz ve öteki ayrışmasının Çiler'in (2006) biz ve onlar ilişkisini aşan bir karşıtlığın yansıması olarak da görülebilir. Sonuç olarak incelenen haberlerin söylem-biliş-toplum bağlamındaki belirgin nitelikleri şöyle özetlenebilir;

- Söylem: İdeolojik, Sinsi, Ümmetçi, Irkçı, Türkçü, Dinsel, Garip / Yeni, Milli, Manevi, 2023, Ahlaklı

- Biliş: Laiklik Anlayışları, Iktidar ve Rejim Anlayışları, Din ve Bilim Çatışması Anlayışları, Modernlik ve Geleneksellik Anlayışları, Tartışmaları, Yeni Türkiye Anlayışları

- Toplumsal/Siyasal Yapılar: Korku Politikası, Referandum, Rejim

Berkant ve Cömert'in (2013) saptadığı üzere eğitimle ilgili haberlerin gazetelerde yer alma düzeyi nicelik olarak görece yetersizdir. Bu çalışmanın bulguları doğrultusunda bu yetersizliğe nitelik boyutunu da eklemek yanlış olmayacaktır. Değerler eğitimine ilişkin haberlerin tamamı olmasa da önemli bir bölümünde eğitim sürecinin kendine özgü ilkeleri ve özelliklerinin gözetilmediği söylenebilir. Değerler eğitimi ve dolayısıyla yeni müfredat çalışmaları çeşitli simgeler aracılığıyla siyasi görüşlerin çatıştığı bir alan niteliğindedir. Atatürkçülük ve evrim teorisi bağlamındaki tartışmalar bunun göstergesi niteliğindedir. Bu bağlamda İslamcılık ve Kemalizm olarak tanımlanan iki ideoloji arasındaki bir gerilim ve tartışmanın (Çiler, 2006) ya da daha saptayıcı bir tanıma muhafazakâr ve seküler/modern ayrışmasının yansıması olan bir tür kültür savaşı (Shortell, 2011) söz konusu edilebilir. Gazeteler, laiklik etrafındaki tartışmalarda kendi ideolojileri doğrultusunda kavramsal anlayışlar üretmektedirler ve laikliğin ya da seküler anlayışın medyadaki yeniden üretim süreçleri, laikliği ötekileşmenin öznesi veya nesnesi haline de getirebilmektedir (Öztaş, 2016). Bu durum bu çalışmanın bulguları ile de örtüşmektedir.

Evrim konusu her zaman tartışmalı ve özellikle medya açısından da ilgi çekici bir konu olagelmiştir. Allgaier ve Holliman'ın (2006) belirttiği üzere konu eğitim bağlamında da her zaman gündemde olmuştur. Hayatın kaynağına ilişkin olarak bilimsel açıklamaların yanında dini açıklamaların da okullarda öğretilip öğretilmemesi gerektiğine ilişkin sorun birçok ülkede ciddi tartışmalara yol açmıştır ve bu tartışmaların önemli bir alanı da medyadır. Medyanın konuyu yansıtma tarzı evrimcilik/yaratışçııı ve müfredattaki yeri hakkındaki kamuoyu anlayışının oluşumunda önemli bir etkiye sahiptir (Allgaier ve Holliman, 2006). Türkiye açısından söz konusu medya etkisinin oldukça sınırlı ve keskin kamplaşmaların betimlediği bir çerçevede oluştuğu söylenebilir. Bu çalışma kapsamında incelenen haberlerde de keskin tartışmalar eşliğinde gazetelerin kendi dünya görüşleri doğrultusunda kamuoyunu evrim konusu bağlamında etkilemeye çalıştıkları söylenebilir. Türkiye'deki gazete haberlerinde genel olarak evrim konusunun bilimsel açıdan oldukça sınırlı bir biçimde verildiğine ilişkin bulgular (Adaklı, vd., 2008) bu çalışmanın bulguları açısından da geçerlidir. Söz konusu sınırlıık değerler eğitimi ve müfredat çalışmaları bağlamında da dikkat çekmektedir. Aynı zamanda evrim konusunun bilimsel açıdan sınırlı, ideolojik bir çerçevede ve sansasyonel bir tarzda işlenmesi de değerler eğitiminin medyadaki temsilini olumsuz etkilemektedir. Anılan bulgular medyada evrim konusundaki haberlerin ideolojik nitelikte olduğu, laikçi ve İslamcı gazeteler arasında keskin bir karşıtlığın bulunduğu, merkez medyada ise sansasyon değerinin öne çıktığına ilişkin bulgular (Adaklı, vd., 2008) ile de uyumlu görünmektedir. Berkant ve Cömert'in (2013) özellikle bazı konularda yapıcı yorumlar yapmak ya da çözüm yolu bulmak yerine medyada karamsar bir yaklaşım sergilenmesine ilişkin saptamalarının değerler eğitimi, müfredat 
çalışmaları ve evrim gibi konular için de geçerli olduğu söylenebilir. Gerçekte tartışmalı politik konuların öğretimine ilişkin keskin tartışmalar esasen kaçınılmazdır (Hess, 2005). Günal ve Kaya'nın (2016) ifade ettiği üzere ailelerden gelebilecek tepkiler gibi nedenlerden dolayı okullarda tartışmalı ve hassas konuların işlenmesinde öğretmenlerin de çekinceleri olmaktadır. Öte yandan tartışmalı konuların okullarda öğretimi ve tartışılmasının demokratik düşünceyi desteklediğine ilişkin bulgular söz konusudur (Hess, 2005). Bu saptama medyadaki tartışmalara da uyarlanabilir ancak incelenen haberler söz konusu edildiğinde medya düzeyindeki tartışmanın demokratik bir zenginliğin sınırlarını zorladığı ve olası tepkilerin yeterince dikkate alınmadığı söylenebilir.

Ayers'in (2005) ifade ettiği üzere dil toplumsal eylemi inşa etmektedir ve söylem, anlamların yaratıldığı ve değiştirildiği bir alan niteliğindedir. Bu çerçevede incelenen haberlerde kullanılan dil ve söylem, değerler eğitimi ya da müfredat hakkında olumlu ve olumsuz nitelikteki anlamların yeniden üretildiği alanlar olarak görülebilir. Bu süreçte gazeteler ideolojilerini de okuyucuya aktarmaktadır (Gonzalez-Carriedo, 2014). Anlamların üretildiği alan niteliğindeki haberler üzerinde, gazetenin genel yayın politikaları, gazetecilerin nitelikleri, haber yapmanın kendi şartlarından kaynaklanan zorluklar ve belirli etkenler farklı düzeylerde etki etmektedir. Haberleştirme süreci, gazete sahibinin dünya görüşü, politik tartışmalar, reklam verenler gibi farklı kesimlerin etkileri ile şekillenmektedir (Kılıç, 2005; Aydın, 2013). Bütün bu etkilerin varlığı söz konusu olmakla birlikte, bu çalışma kapsamında incelenen haberler açısından siyasi duruş ve iktidara ilişkin yaklaşımın ve buna bağlı olarak ideolojik bakış açısının belirginleştiği görülmüştür. Haberleştirme sürecinde farklılaşmanın ortaya çıkması doğal bir olgu niteliğindedir. Benzer bir saptama Taşdemir ve Kuş'un (2011) yenilenen müfredata ilişkin araştırmalarında da söz konusu olmuştur; Buna göre ulusal gazetelerde programa ilişkin olarak birbirinden farklı değerlendirmeler olduğu bulgulanmıştır. Bazı gazetelerde "eğitimde devrim", "eğitimde reform", "eğitim sil baştan" "tepeden tırnağa/baştan sona yenilenme", "umut ve heyecan verici" biçiminde temaların vurgulandığı bazı gazetelerde ise, "yeni müfredat zayıf", "müfredat yok kavga var" temaları ile konunun haberleştirildiği görülmüştür. Benzer bulgulara bu çalışmada da ulaşılmıştır. Çiler'in (2006) "İslamcı" medya ve "seküler" popüler medyanın söylemsel stratejileri arasında farklııklar ve benzerlikler olduğuna ilişkin bulguları da bu çalışmanın bulguları ile uyumludur. Çalışma grubunda yer alan olumsuz ve karşıt nitelikteki haberlerde siyasi iktidara ilişkin olarak karşıt bir duruşun açık bir biçimde etkili olduğu görülmektedir. Ana akım gazeteler, teknik olarak nitelendirilebilecek eleştirilerle müfredat ve değerler eğitimi çalışmalarını ele alırken diğer gazetelerin siyasal dünya görüşleri doğrultusunda keskin ve sert bir karşı duruş sergiledikleri görülmektedir. Olumlu ve destekleyici nitelikteki haberlerde muhafazakâr ve dolayısıyla iktidarın yanında duran bir anlayışın etkili olduğu açıktır. Ders yükünün azaltılması, değerler eğitimi uygulamalarının milli ve manevi değerler açısından önemi ve müfredattaki yenileşme öne çıkarılırken, konunun tartışmalı boyutları ya görmezden gelinmiştir ya da bürokratların ve uzmanların dilinden yorumlanarak eleştiriler haksı konuma getirilmeye çalışıımıştır. Destekleyici haberlerde yenilik vurgusu varken eleştirel haberlerde var olanın değiştirilmesinin olumsuzluğuna vurgu dikkat çekmektedir. Haberleştirme tarzında ve söylemde yansıyan siyasi duruş ve kamplaşmalara iliş̧kin bulgular ve saptamalar (Aydın, 2013; Küçüközyiğit, 2015; Ongun, 2014) dikkate alındığında örneğin sığınmacılarla ilişkin haberlerde de bu saptamaları destekler tarzda tipik sonuçların ortaya çıktığı görülmektedir. Göktuna Yaylacı'nın (2017) bulgularına göre medyadaki temsiller bağlamında Suriyeliler, iç siyasete ilişkin bir takım kamplaşmaların ve kavgaların sonucunda ortaya çıktığı söylenebilecek bir tür kıskançlığın hedefi olabilmektedir. Gazetelerin ideolojik perspektiflerine dikkat çeken Göker ve Keskin de (2015) haberlerde Suriyeli mültecilerin, toplumsal sorunların merkezinde konumlandırıldığını bulgulamıştır. Suriyeli mülteciler genel olarak edilgen ve mağdur olarak tanımlanmakla birlikte 'günah keçisi' olarak da gösterilmektedir. Yine benzer bir bulgu Wikileaks belgelerine ilişkin olarak farklı siyasi görüşleri temsil eden iki gazeteye iliş̧in bir çalışmada da söz konusu olmuştur. Her iki gazetenin de Wikileaks belgelerini araçsallaştırarak ideolojik bir savaşın tarafları rolünü üstlendikleri (Toruk ve Sine, 2012) bulgulanmıştır. Birbirinden oldukça farklı bağlamlarda medyanın haberleştirme tarzındaki ideolojik etkinin varlığı dikkat çekicidir. Aslında eğitim söz konusu 
olduğunda örneğin siyasal partilerin görüşlerinde de savundukları siyasal ideolojilerinin ve politik kimliklerini belirleyen unsurların ön plana çıktığına (Tok, 2012) ilişkin bulgular düşünüldügünnde medyanın anılan tavrının da toplumsal olarak eğitime ilişkin genel anlayışın etkisini taşıdığı söylenebilir. Bu bulguların yanı sıra bazı konulardaki haberleştirme örneklerinde siyasi duruşun etkisine ilişkin bulgulardan bahsedilmemesi de (Teyfur, 2014) söz konusu olabilmektedir. Herbert'in (2000) vurguladığı üzere haber kararları üzerinde "olay/konu", "gazeteci", "kurumsal organizasyon" ve "dış etmenler" etkili olmaktadır (aktaran Kılıç, 2005). Bu durumda olay/konu etkeninin bazı bağlamlarda siyasi duruşun etkisini daha belirginleştirmeye olanak sağladığı düşünülebilir. Değerler eğitimi, yeni müfredat, evrim, Atatürk gibi konu başlıkları siyasi duruşların etkili olduğu alanlar niteliğindedir. Aynı zamanda eğitim konusu söz konusu olduğunda medyanın genel tavrının görece olumsuz olduğu söylenebilir. Medyada eğitim konusu genel olarak eğitim politikalarını şekillendiren krizlere ilişkin mesajlar (Cohen, 2010) çerçevesinde şekillenmektedir. Örneğin Çetin ve Demirkasımoğlu (2015), beş yılı kapsayan bir süreçte öğretmen ve yöneticilere ilişkin haber yapan sol, muhafazakâr ya da merkez eğilimli gazetelerin hepsinde olumsuz imajın ağır bastığını bulgulamıştır. Yine Altun (2014) farklı bir çalışmada öğrenci, öğretmen ve idarecilere ilişkin haberlerin büyük bir oranda olumsuz haberler olduğunu saptamıştır.

Profesyonel habercilik kodları açısından bakıldığında gazetelerin yetersiz olduğu yönündeki saptamalar oldukça haklı görülmektedir. Gazetelerin birincil işlevinin bilgilendirmek olduğu kabul edilirse ve günümüzde hakikat ve nesnellikten uzaklaşmaları bu işlevi olumsuz etkilemektedir. Gazetelerin formal eğitim süreçlerine etkileri dikkate alındı̆̆ında, gazetelerin daha kapsamlı ve nitelikli eğitim haberlerine yer vermelerinin önemi de ortaya çıkmaktadır (Toruk ve Sine, 2012; Berkant ve Cömert, 2013). Ancak bu noktada, tarafsız ve aynı zamanda akıl ve bilime önem veren medya yerine yaygınlaşmaya başlayan tarafgir medyanın varlığının demokratik toplum ve gazetecilik açısından olumsuzluğuna (Berkant ve Cömert, 2013) ilişkin saptamaların da tutarlı ve anlamlı olmadığı açıktır. Tarafsızlığı ve akla ya da bilime dayanmayı indirgemeci bir bakışla sadece iktidara ilişkin olumsuz ya da eleştirel bir duruş ile ilişkilendirmek haberleştirme sürecinde etkili olan diğer unsurların göz ardı edilmesine yol açmaktadır. Çünkü esasen toplumsal aktörler başkalarının dünya görüşlerini duymak ve onları ikna etmek için bir tür rekabet içerisindedirler (Shortell, 2011). Çok sayıda araştırmanın yanı sıra bu çalışmanın bulguları da siyasi duruşun iktidar yanlısı ya da karşıtı olmanın ötesinde etkileri olduğunu ve bu etkilere bağlı olarak haberleştirme süreçlerinin ideolojik kamplaşmaların yansımalarına dönüştüğünü göstermektedir. Medyanın bütünüyle ideolojisiz ve mutlak anlamda nesnel bir söylem ve anlam inşa etmesini beklemek gerçekçi olamayacağı gibi tutarlı da değildir. Önemli olan haberleştirme süreçlerindeki etkilerin bilincinde bilinçli okuyucuların varlığı ve medya organlarının olabildiğince farklı yorumlara açık olabilmesidir.

Değerler eğitimi güncelliğini korumaktadır ve eğitim sistemindeki düzenlemeler bağlamında sürekli gündemde olmaya devam edecektir. Güncel bir eğilim niteliğindeki değerler eğitimi konusunda çok sayıda kitap ve bilimsel makale yayınlanmış, lisansüstü tez hazırlanmıştır. Bu çalışmalardan kamuoyunun daha çok haberdar olmasının imkânları oluşturulmalıdır. Değerler eğitiminin bilimsel ve akademik boyutlarının daha iyi anlaşılması özellikle medyadaki tartışmalarda konunun söz konusu boyutların dışında ele alınmasının olumsuz sonuçlarının giderilmesine katkı sağlayabilir. Sert ve keskin tartışmaların gazetelerin siyasi duruşları ile ilgisi açık olmakla beraber, gerek müfredat çalışmalarında gerek değerler eğitimi bağlamında tarafların/paydaşların süreçlere daha geniş ve çok boyutlu katılımının sağlanması, medya organları ve kamuoyuna dönük olarak sürece ilişkin bilgilendirmelerin yine çok boyutlu bir biçimde yapılmasının önemi de ortadadır. Değerler eğitimin medyada temsil edilişine ilişkin olarak daha geniş dönemleri kapsayan bilimsel çalışmaların yapılması önem taşımaktadır. Değerler eğitiminin eleştirel bir bakışla ve hak ettiği düzeyde değerlendirilebilmesi için böylesi çalışmalar büyük katkı sağlayacaktır. Bu araştırma süreçlerine başta medya organlarının temsilcileri, haber yazarları ve köşe yazarları gibi tarafların da katıımı sağlanabilir. Böylece medya temsilinin arkasındaki düşünsel zemin daha iyi analiz edilebilir. 


\section{Kaynakça}

Adaklı, G., Gülsaçan, M. ve Gökçümen, Ö. (2008). Representations of Evolutionary Theory in Turkish Press Media. 2. Avrupa Iletişim Konferansı. European Communication Research and Education Association, ECREA Barcelona.

Aktaş, E. ve Beldağ, A. (2017). Kalila and Dimna as One of the Traditional Antecedents of Modern Classifications of Values. International Education Studies, 10(3), 46-53.

Allgaier, J. ve Holliman, R. (2006). The Emergence of the Controversy Around the Theory of Evolution and Creationism in UK Newspaper Reports. The Curriculum Journal, 17(3), 263-279

Altun, A. (2014). Öğrenci, Öğretmen Ve Idareci Ne Yaparsa Haber Olur? International Journal of Human Sciences, 11(2), 871-893.

Aydın, F. B. (2013). Haber Söyleminde Siyasal Etki ve Ideoloji: 2002 ve 2011 Genel Seçimlerinin Karşılaştırmalı Analizi. Selçuk Üniversitesi Sosyal Bilimler Enstitüsü Gazetecilik Anabilim Dalı. Yayınlanmamış Yüksek Lisans Tezi.

Ayers, N. F. (2005). Neoliberal Ideology in Community College Mission Statements: A Critical Discourse Analysis. The Review of Higher Education, 28(4), 527-549.

Beldağ, A. (2016). Values Education Research Trends in Turkey: A Content Analysis, Journal of Education and Training Studies, 4(5), 101-112.

Berkant, H. G. ve Cömert, M. (2013). Günlük Gazetelerdeki Eğitimle İlgili Haberlerin İncelenmesi. KSÜ IiBF Dergisi, 3(2), 25-44.

Berkowitz, M. W. (2011). What Works in Values Education. International Journal of Educational Research, 50(3), 153-158.

Çetin, S. K. ve Demirkasımoğlu, N. (2015). Öğretmen ve Yöneticilerin Etik ve Etik Dışı Davranışlarının Basına Yansımaları. Sosyal ve Beşeri Bilimler Araştırmaları Dergisi, 34, 95-110.

Cohen, J. L. (2010). Teachers in the News: a Critical Analysis of One US Newspaper's Discourse on Education, 2006-2007. Discourse: Studies in the Cultural Politics of Education, 31(1), 105-119.

De Swert, K., Schacht, L. ve Masini, A. (2015). More Than Human Tragedy? A Quantitative Comparison of Newspaper Coverage on Irregular Migration and Lampedusa in Five European Countries. Italian Studies, 70(4), 506-520.

Dursun, Ç. (2006) The Struggle Goes On: The Discursive Strategies of the Islamist Press in Turkey. Journal of Contemporary European Studies, 14(2), 161-182.

Göker, G.; Keskin, S. (2015). Haber Medyası ve Mülteciler: Suriyeli Mültecilerin Türk Yazılı Basınındaki Temsili. Iletişim Kuram ve Araştırma Dergisi, 41, 229-256.

Göktuna Yaylacı, F. (2017). Eskişehir Yerel Basınında Mülteciler ve Suriyeliler. Sosyoloji Araştırmaları Dergisi, 20(1), 1-40.

Gonzalez-Carriedo, R. (2014). Ideologies of the Press in Regard to English Language Learners: A Case Study of two Newspapers in Arizona. Critical Inquiry in Language Studies, 11(2),121-149.

Günal, H. ve Kaya, R. (2016). Tarih Öğretmenlerinin Tartışmalı Ve Hassas Konuların Öğretimi Sırasında Yaşadıkları Çekince Ve Sorunlar (Erzurum Örneği). Türk Tarih Eğitimi Dergisi, 5(1), $44-73$. Retrieved from http://dergipark.gov.tr/tuhed/issue/26593/279913

Günay, V. D. (2013). Söylem Çözümlemesi. İstanbul: Papatya

Güngör, E. (1998). Değerler Psikolojisi Üzerinde Araştırmalar. İstanbul: Ötüken.

Gür, T. (2013). Post-Modern Bir Araştırma Yöntemi Olarak Söylem Çözümlemesi. Zeitschrift für die Welt der Türken, 5(1), 185-202.

Happer, C. ve Philo, G. (2013). The Role of the Media in the Construction of Public Belief and Social Change. Journal of Social and Political Psychology, 1(1), 321-336.

Hess, E. D. (2005). Controversies about Controversial Issues in Democratic Education. PS: Politics and Society, 37(2), 257-261.

Kenan, S. (2009). The Missing Dimension of Modern Education: Values Education. Educational Sciences: Theory \& Practice, 9(1), 259-295. 
Kılıç, D. (2005). Haber Yapma Sürecinin Belirleyici Unsurları ve Basın Ahlakı. Selçuk Iletişim, 3(4), 130 141.

Küçüközyiğit, U. (2015). Hacı Bektaş Veli Anma Törenleri ve Kültür Sanat Etkinlikleri Hakkındaki Haberler: Bir İçerik Analizi. Türk Kültürü ve Hacı Bektaş Velî Araştırma Dergisi, 75, 29-48.

Lickona, T. (1991). Educating for Character: How Our Schools Can Teach Respect and Responsibility. New York: Bantam Books.

Lim, L. (2014). Ideology, Rationality and Reproduction in Education: a Critical Discourse Analysis. Discourse: Studies in the Cultural Politics of Education, 35(1), 61-76.

MEB, (2005). Sosyal Bilgiler Programı. http://ttkb.meb.gov.tr/program2.aspx?islem=1\&kno=39. Erişim tarihi. 10.04.2016

MEB, (2018). Sosyal Bilgiler Öğretim Programı. http://mufredat.meb.gov.tr/ ProgramDetay.aspx?PID=354. Erişim tarihi. 01.02.2018.

Ongun, Ö. (2014). Uluslararası Habercilik ve Söylem: Türkiye'deki Gazetelerin Suriye iç Savaşını Yansıtma Biçimleri. iletişim, 20, 77-97.

Öztaş, F. (2016). Türkiye'de Yazııı Basının Laiklik Kavramına Bakışı. Atatürk Üniversitesi Sosyal Bilimler Enstitüsü Dergisi, 20(4), 1201 -1217.

Rogers, R., Schaenen, I., Schott, C., O'Brien, K., Trigos-Carrillo, L., Starkey, K. ve Carter Chasteen, C. (2016). Critical Discourse Analysis in Education: A Review of the Literature, 2004 to 2012. Review of Educational Research, 4(86), 1192-1226.

Rogers, R., Malancharuvil-Berkes, E., Mosley, M., Hui, D. ve O'Garro-Joseph, G. (2005). Critical Discourse Analysis in Education: A Review of the Literature. Review of Educational Research, 75(3), 365-416

Shortell, T. (2011) The Conflict over Origins: A Discourse Analysis of the Creationism Controversy in American Newspapers, Mass Communication and Society, 14(4), 431-453.

Sutrop, M. (2015). Can values be taught? The Myth of Value-Free Education. Journal of the Humanities and Social Sciences, 19(2), 189-202.

Taşdemir, A. ve Kuş, Z. (2011). Yenilenen Illköğretim Programı ile ilgili Ulusal Gazetelerde Yayınlanan Haberlerin İçerik Analizi. Kuram ve Uygulamada Ĕ̆itim Bilimleri, 11(1), 1-23.

Taylor, S. (2004). Researching Educational Policy and Change in 'New Times': Using Critical Discourse Analysis. Journal of Education Policy, 19(4), 433-451

Teyfur, M. (2014). Basında Yer Alan Okullarda Şiddet Ile Illgili Olayların Değerlendirilmesi. Illköğretim Online, 13(4), 1311-1330

Tok, T. N. (2012). Türkiye'deki Siyasal Partilerin Eğitim Söylemleri ve Siyasaları. Kuram ve Uygulamada Eğitim Yönetimi, 18(2), 273-312

Toruk, İ. ve Sine, R. (2012). Haber Söylem Üretimindeki İdeolojik Etki: Wikileaks Haberleri. Türkiyat Araştırmaları Dergisi, 31, 351-178.

Van Dijk T. A. (1988). News as Discourse. New Jersey: Hillsdale.

Van Dijk T. A. (2009). Critical Discourse Studies: A Sociocognitive Approach. in Methods of Critical Discourse Analysis (Eds.) Wodak, R. and Meyer, M. London: Sage, pp. 62-85

Van Dijk, T. (2015). Critical Discourse Studies: A Sociocognitive Approach in Methods of Critical Discourse Studies (Eds) R. Wodak and M. Meyer. London: Sage, pp.62-85

Wodak, R. and Meyer, M (2009). Critical Discourse Analysis: History, Agenda, Theory and Methodology in Methods of Critical Discourse Analysis (Eds.) Wodak, R. and Meyer, M. London: Sage, pp. 1-22

Zarillo, J. J. (2012). Teaching Elementary Social Studies. Boston: Pearson.

Zhu, X. (2006) Moral Education and Values Education in Curriculum Reform in China. Frontiers of Education in China, 2, 191-200. 


\section{Extended Summary}

Values education understanding is coming to the fore mostly as a tendency to overcome societal problems faced in connection with values in the world and shortcomings of the education systems that are thought to have led to divergence from values. This situation was experienced in Turkey for the first time through the Social Studies curriculum in 2005, then values education took place in different courses. Values education is increasingly becoming the destination of more intense interest. Besides academic interest reflected in the number of published articles and thesis, recent regulations particularly regarding education curricula have made values education an important topic of debate in public opinion as well. In particular, in the context of the 2017 curricula updating process, values education understanding can be seen in all draft curricula under construction.

\section{Aim}

The aim of this study is to analyse the media representations concerning values education and carry out a multidimensional evaluation accordingly.

\section{Method}

Research Design. This study was designed as a qualitative study as it intended to analyse media representations of values education in connection with newspaper articles and to suggest a multidimensional evaluation. To this end; the new stories about values education appearing in nation-wide Turkish newspapers between January 1, 2017 and March 7, 2017 were reviewed from a socio-cognitive point of view by means of critical discourse analysis. Study Group. Due to the date when drafts of curriculum update studies were introduced to public debate, the news stories on values education appearing in nation-wide Turkish newspapers from January 1, 2017 to March 7, 2017 were appointed as study group. Relevant news stories were accessed via PRNet Program. The scanning yielded 15 national newspapers (in alphabetical order) publishing articles on values education: Aydınlık, Birgün, Cumhuriyet, Güneş, Habertürk, Hürriyet, Karar, Milliyet, Posta, Sözcü, Star, Türkiye, Vatan, Yeni Akit, Yeni Şafak. In these newspapers, a total of 50 texts were analysed, including 39 news stories and 11 columns. Data Analysis. In order to facilitate interpretation of the data and display general features of the news during discussion stage; first, data were reported regarding the number of news and columns by newspaper, distribution of the news by publication date, and topics of the news in general. In the second stage, the news stories were reviewed with critical discourse analysis. In this study, it was attempted to apply critical discourse analysis departing from Van Dijk's (2015) socio-cognitive approach. Socio-cognitive approach deals with the process of language use and investigation of mental representations as well as knowledge, ideology and other beliefs shared by social groups as users generate discourses or comprehend a discourse and engage in verbal interaction (Van Dijk, 2009). The socio-cognitive approach formulated by Van Dijk (2015) with discourse-cognition-society triangle refers to a much broader framework than a mere method.

\section{Discussion and Conclusion}

In this study, the news on values education published in national newspapers between January 1 , 2017 and March 7, 2017, considering the date when drafts of curriculum update studies were introduced to public debate when values education played a central role, were analysed by means of critical discourse analysis with a socio-cognitive approach. According to the study findings, the newspapers spare very limited room for news about values education. Particularly, progovernment and anti-government papers, and criticizing mainstream newspapers were seen not to give much room for the topic. It can be said that values education was not discussed as heavily as required or consistently with educational sciences at least in that period. It was found out that important discussions in the literature or field experts' views were not included while giving 'acceptable' or 'weird' examples of values education. Rather, values education was seen to be reported as news based on the basis of debates, polarizations and disintegration in the wider social/political environment, also covering the education process. A dramatic impact of political 
worldviews on media representations was seen in the news about values education. It goes without saying that education is not an independent activity from the political context, and thus it is more than natural and inevitable to discuss it in that connection. Still, even in this case, there seems to be no reasonable account for not benefiting from the data of educational science in an impartial and just manner.

The findings of this study regarding values education and curriculum studies can be expressed on the basis of the ideological construct of discourse proposed by Van Dijk (2015: 73-74): Polarization can be seen in both pro and con examples. All they are embedded with the description of positive internal group versus negative outer group, and political fractions between "we" and "they". In the examples on the opposite side; "we" refers to Kemalist, secularist and scientistic people, while "other" has religious, panislamist, anti-scientific, and traditionalist connotations. On the other side, positive and supportive news imply Muslim, conservative, pro-new Turkey, and loyal to values with "we"; however, "other" has underpinnings such as ideological, secular, detached from national and spiritual values, and belonging to the old Turkey. As a conclusion, the prominent qualities of the news articles examined in the context of discourse-cognition-society can be summarized as follows; Discourse: Ideological, Sneaky, Panislamist, Racist, Turkist, Religious, Strange/New, National, Spiritual, 2023, Moral. Cognition: Secularism Approaches, Ruling and Regime Approaches, Approaches of Science and Religion Conflict, Modernity versus Traditionalism Approaches, Discussions, New Turkey Approaches. Social/Political Constitutions: Fear Policy, Referendum, Regime A better understanding of the scientific and academic dimensions of values education can contribute to elimination of negative consequences of addressing the topic from irrelevant perspectives, especially in the discussions in the media. Although the harsh and sharp discussions are clearly related to the political stance of the newspapers, it is also important to have a wider and multidimensional involvement of the parties/stakeholders in the process of curriculum studies and values education, as well as informing the media and public about the process from a multidimensional point of view. It is considered important to carry out scientific studies to cover broader periods concerning representation of values education in the media. 